\title{
Vision Based Industriael Case Southwest Airlines
}

\author{
Gastélum James, Omar Alejandro and José G Vargas Hernández* \\ Department of Economic and Administrative Sciences, University of Guadalajara, Mexico \\ *Corresponding author: José G Vargas Hernández, University Center for Economic and Administrative Sciences, University of Guadalajara, Mexico
}

Submission: 監July 26, 2018; Published: 監 August 08, 2018

\begin{abstract}
Summary
In this paper the airline industry is studied in the US and how the environment affects this Southwest Airlines, the market leader based on passengers. Industrial Organization (IO) presents the vision based on resources for analysis, where Porter's five forces are used as a guiding tool: [1] low entry barriers pose a threat of entrants to compete with Southwest Airlines companies, which in the longer [2] adds high-intensity among competitors and the threat of [3] power potential of buyers and [4] suppliers in the industry. Perhaps that solves the profitability of the seemingly unattractive industry is enjoying not having [5] the threat of substitutes. Once analyzed industry, an analysis of the cost leadership strategy is done by Southwest Airlines, one of the three generic strategies Michael Porter. Throughout the work, it seeks to support the arguments of the OI with microeconomic theory, where there is a congruence between the two areas of knowledge.
\end{abstract}

Abstract

This document studies the airlines industry in the United States, analyzing how Southwest Airlines Affects esta environment, based on enplanements ITS leader. The Industrial Organization (IO) sets the industry based view For This analysis, in which Porter's Five Forces Where Model is used as tool [1]. The few entry barriers in the industry Represent a threat of potential competitions for Southwest Airlines, Which sums to the current [2] intense competition Between companies Already in the industry, and the potential threat that [3] customers and [4] They mean suppliers. But the virtually inexistent [5] Threat of substitutes, might be what settles the industry's profitability. Once Analyzed the industry, the study proceeds to analyze the cost leadership strategy as on of Porter's Generic Strategies, during the study.

Keywords: Toerolíneas; Vision based on industry; Porter's five forces; Threat of substitutes; leadership strategy

\section{Introduction}

In this work different visions raised by the Industrial Organization (IO) and their models to understand how companies make strategic decisions by microeconomic theory explaining the concepts on which is based OI is studied. Throughout the study, an analysis of the application of these theoretical approaches by the US airline Southwest Airlines develops. The structure-conductperformance model was introduced by the IO where it is suggested that the industry structure defines the company shares (behavior), and the latter also define the performance of it. Understanding the performance as the final outcome of the decisions taken by the company to the circumstances that it faces, the OI first proposes a study of the external environment in which the company develops, it followed internal study of the capabilities of the company itself. For external study proposes a vision based on industry while from for internal study suggests the vision based on resources [4].

So first vision-based industry is studied, which is based on the structure of the five forces of Michael Porter, where it is stated that the higher is the competition in an industry, the more complicated the company to profit. It seeks to determine whether there are barriers to entry, intensity of rivalry among existing competitors, pressure from substitute products, bargaining power of buyers and bargaining power of suppliers in the airline industry in the US and how and through the concepts of market structures microeconomic theory, how these forces affect Southwest. Even under the vision based on industry, it seeks to know how that Southwest facing these five forces and from their knowledge, makes decisions.

At this point, microeconomic theory will continue to focus on market structures and integrate producer theory to explain the actions of Southwest. While explaining the actions, OI returns to Michael Porter, who identifies three generic strategies that companies can take to outperform competitors in the industry: cost leadership, differentiation and focus [5]. Up until this point, he had spoken of actions and decisions that companies can take and they define their behavior. It is important to note that both microeconomics, industrial organization as strategies are a plan of action or set of actions taken by a company [4]. Then you can talk about strategies both actions in the study.

\section{History of southwest airlines}

In 1967, Rollin King and Herb Kelleher founded Southwest Air, airline initially devoted to flying within the state of Texas, United 
States. In 1971 when the company was established, appointing Southwest Airlines Co. and comes into operation, offering flights between the cities of Dallas, Houston and San Antonio with three Being 737-200 units. The strategy of staying in Texas and concentrate its bid was successful, having already 100 flights per week to October 1972.

Under the vision of its founder, Herb Kelleher, Southwest Airlines ideas then implemented successful corporate culture of Pacific Southwest Airlines. Among them stood a special selection of its flight attendants described with like cheerleaders attractive appearance and unique personality, which dressed in shorts and tight pants and go-go boots. This theme of "Long Legs and Short Nights" was a success at the time. Even the president of the company in 1971, Lamar Muse, told the The New York Times that this strategy had proven successful repeatedly and Southwest Airlines did not affect him a copy of the strategies of Pacific Southwest Airlines is considered.

In 1972, after years of legal confrontations to obtain the right to operate, a shortage of funds threatened to close the company. To reduce costs, the company decided to sell one of its four aircraft and calculated that it could make airplanes would last no more than ten minutes at the gates between landing and take off again, and thus be even more profitable. So he was born known and successful strategy "after ten minutes." Before the deregulation of airlines in the United States in 1978, where the federal government imposed restrictions on entry, prices and destinations, in February 1979, Southwest offered its first flight outside the state of Texas, the city of New Orleans, Louisiana.1985 Southwest acquired for $\$ 60.5$ million in stock and cash airline Muse Air, which was on the verge of bankruptcy. Upon completion of the acquisition, Southwest renamed Muse Air to TranStar Airlines, making it a wholly owned subsidiary that will operate as an independent airline. But in 1987 he sold TranStar Texas Air to compete with this in a price war.

In 1990, Southwest acquired Morris Air for \$134 million in shares. By completing the acquisition, Southwest took the capital and routes of Morris Air. Thus, the company acquired routes in the northwest. In the first months of 2000, Southwest Airlines began its proactive recruiting coverage for stabilizing fuel prices. In 2008 , Southwest paid $\$ 7.5$ million to acquire certain assets of the bankrupt airline ATA Airlines. The main reason for this acquisition were operating licenses and landing at LaGuardia Airport in New York with ATA counted.

In 2011, Southwest completed the acquisition of Air Train Airways to buy all the assets of common stock, corporate identity and operation of the airline. By purchasing, Southwest acquired access to the Atlanta airport, international service and additional landing slots at airports in Washington-Reagan Wahsington, DC and LaGuardia. In the same year, for the tenth consecutive year, Fortune magazine recognized Southwest Airlines in its annual survey of corporate reputation and placed the company enters the three most admired US corporations across all industries.

In 2016 Southwest Airlines is the airline with the largest market share in the United with incomes above the US \$3,500 million and shares sold at a price of $\$ 65.45$ on the stock market in New York, which had an approximate increase of 30 percent over the previous year and about 540 percent growth compared to the last five years. So you can say that Southwest Airlines is the market leader company, through the implementation of strategies and operational structure, as in the case of acquisitions. Based on the foregoing background you can also note the importance of institutions for airlines, as was the case of deregulation, where you can say that the government changed the rules of the game.

\section{Vision-based industry}

The first step in analyzing a company by industry-based vision is to define what industry is that this is. Therefore, it is important to first define what is an industry for both industrial organization and microeconomic theory, since for both the first step in the study of an industry is its definition. Luckily, there are different to the concept. Industrial organization defines an industry as the group of firms producing similar goods [4]. While microeconomic theory understands producers (companies) that offer the same goods [4]. For fine of this study will also be important to identify market and industry concepts as similar, but seeing the market as a more complete concepts, where it is considered as the place where consumers, producers and state exchange goods [1]. Generally, industrial organization will refer to industries, while microeconomic theory tend to refer to the market.

Understanding these definitions, we can say that the industry it belongs Southwest Airlines is the airline industry, which produces a good, but the air transport service, is understood as your product. For purposes of analysis delimitation of the domestic airline industry is studied in the United States, ie, only those flights of origin and destination that country, carried out by US carriers is studied. Once established industry, Proceed to analysis thereof by the structure of the five forces proposed by Michael Porter in his Competitive Strategy (1982), commonly known as the five Porter forces. The model suggests that between stronger these forces will be more difficult for companies to generate profits and could be seen as an unattractive industry to belong. Consistent with this, microeconomic theory states that in a market structure of perfect competition benefits the producers are zero, then understanding that in a competitive market (that which tends to perfect competition) will not be one that provides large surpluses for producers [4]. Understanding then that the more store industry to a market structure of perfect competition, Then, Based analysis each of the forces occurs.

\section{Structure Porter's Five Forces}

\section{Entry barriers}

As mentioned before, companies are interested in joining profitable industries, so it is expected to enter those they are, but there are natural barriers to entering them, or sometimes prevent it, what are known as barriers input. Microeconomic theory states that in a structure of perfect competition there are no such barriers, so it is said that there is free entry $[4,7]$ this raises in its structure by establishing that the risk of new entrants in the industry will 
respond to how big are their barriers to entry. Microeconomics is said that while firms in an industry make profits, there will be incentives for other companies to enter the industry and the entry of these lessen the benefits of all and this trend will continue until the benefits equal to zero [4]. That's why, Porter identifies barriers to entry as positive for those already in the industry. Both microeconomic theory and Porter establish similar ways in which these barriers can occur.

These are entry barriers identified for the airline industry in the United States:

Capital needs: Companies wishing to enter the market require a large capital investment to do so. Operating expenses Southwest Airlines in 2017 exceeded $\$ 7.319$ million. It is understood that Southwest is a leader and expenditures of other companies in the industry are minor, but consider that it is a company with over 50 years of operation and that these aforementioned expenses are only operating now should say the cost of starting operations is much higher.

Institutional regulations: The industry has certifications for operation by different institutions in the United States and licenses. The Federal Aviation Administration, through regulations, controls and requires minimum standards in civil aviation operations in the United States. Other institutions such as the Department of Homeland Security, impose regulations on the industry.

Microeconomic theory explains these barriers to entry explaining how they originate monopolies. It is said that there are natural monopolies a monopoly, which are those where the curves of average production costs of goods are so great that only fit one inside the market demand. Something similar happens in the industry to Southwest, the size of the average cost curve is so great that, even though it should be more than one, represents a barrier to entry.

While explaining the institutional regulations as those barriers imposed by the state, where the exclusive right as a producer of a good is given [4]. It can be concluded that although some entry barriers are mentioned, are not as strong as they are in other industries. An example of an industry with high barriers to entry is the industry of energy services, where therelimits bidders companies by the state and also very large investment required.

\section{Intensity of rivalry among competitors}

This force can be perhaps the easiest to understand, and many industry analysis limited. Level talks that companies that make up the industry are striving to increase its market share. Price wars, advertising and the introduction of new products, are just some of the representatives of this rivalry. Microeconomic theory provides tools for measuring the concentration of a market, ie their competitiveness. An instrument frequently used, especially in America, is the Herfindahl-Hirschman Index (HHI for its acronym in English), where the market shares of the companies join and rise to power equivalent to the number of companies that make up the industry.
The result of the index ranges between 0 and 1 , where 1 represents a monopolistic structure and the tendency to 0 perfect competition. Then the higher result the index, the higher the concentration in the market, meaning an industry with low competition and the smaller it is understood as a competitive market [4]. The Herfindahl-Hirschman calculated for the industry study in 2016 index are analyzed only 10 airlines with greater market share, and to estimate the participation of 128 airlines that operated that year can be complicated and because these 10 are representative of the industry (Table 1). The HHI (0.1156) indicates a competitive market structure, which tends towards perfect competition and share some characteristics. It is important to stress the importance that there are significant differences between a perfectly competitive market and a competitive one. These are the factors that create this rivalry among competitors according to Porter:

Table 1: 10 Airlines greater market share in the US in 2016.

\begin{tabular}{|c|c|c|}
\hline Airline & Participation Rate & HHI \\
\hline South-west & 1.84 & 0.1156 \\
\hline American & 1.75 & \\
\hline Delta & 1.74 & \\
\hline United & 1.22 & \\
\hline Jet Blue & 0.46 & \\
\hline Sky West & 0.38 & \\
\hline Alaska & 0.3 & \\
\hline Express Jet & 0.27 & \\
\hline Spirit & 0.25 & \\
\hline Frontier & 0.18 & \\
\hline
\end{tabular}

Source: Information published by the Bureau of Transportation Statistics of the United States.

1. Numerous or equally strong competitors: Although there are industries with hundreds of thousands of competitors, competing 128 airlines in the United States are few for the nature of your business. It is also important to consider that there is one or a group of companies with significant market share. Southwest Airlines is the leader with only 1.84 percent stake.

2. Slow industry growth: The airline industry has not accelerated growth, so that businesses in it have the resources to generate competition and those who did and left the market.

3. High fixed costs: An important productive resource for airlines are its aircraft, which is a fixed cost of more than $\$ 100$ million, according to Statistics Portal The resulting low profits and encouraging competition.

4. Lack of differentiation or switching costs: Although there are some differences in the services offered by airlines, one can say that the product is very similar among all. Therefore, according to Porter, consumers base their purchase decision 
mainly on price. Microeconomics explains the buying decision process based on the assumption that the consumer is a rational economic agent seeking to maximize their profits [4].

According to Porter [6] it can be said that the airline industry in the United States has strong intensity in the rivalry between competitors. Microeconomic theory is consistent with this conclusion, since the Herfindahl-Hirschman index is proof of this competitive market.

\section{Pressure from substitute products}

Table 2: Market prices for domestic flights in the United States number of passengers (millions) of US Airlines industry from 2003 to 2017 (based 2017 deflation).

\begin{tabular}{|c|c|c|}
\hline Year & Passengers & Price \\
\hline 2017 & 849.3 & 347 \\
\hline 2016 & 824 & 354 \\
\hline 2015 & 798.2 & 377 \\
\hline 2014 & 762.7 & 410 \\
\hline 2013 & 743.2 & 404 \\
\hline 2012 & 736.7 & 401 \\
\hline 2011 & 730.8 & 402 \\
\hline 2010 & 720.5 & 377 \\
\hline 2009 & 703.9 & 365 \\
\hline 2008 & 743.3 & 400 \\
\hline 2007 & 769.6 & 388 \\
\hline 2006 & 744.7 & 389 \\
\hline 2005 & 738.6 & 392 \\
\hline 2004 & 703.7 & 384 \\
\hline 2003 & 647.5 & 422 \\
\hline
\end{tabular}

Source: Data from the Bureau of Transportation Statistics US

Porter [6] defined as those substitute products that perform the same function as the goods offered by the industry. While the micro theory comprising replacers as those goods under certain conditions, may eventually replace another. It can be said that this is another concept where industrial organization and microeconomic theory agree. Porter goes a step further than microeconomics suggesting that, in general, all companies compete against those that produce substitute goods because these goods limited yields in the industry. Then, it suggests that collective action is needed by the whole industry to the threat posed by substitutes, especially when they offer a better price-performance. Microeconomic theory explains this phenomenon through price elasticity in demand for goods. To meet this elasticity, it is first necessary to meet market demand. A linear regression to estimate it with the data in Table 2 , where data are market prices and the number of passengers (in millions) in the United States was made, both concepts from 2003 to 2017. He took as dependent variable number of passengers, which was interpreted as demand and the independent variable was the price. This allocation allows the economic interpretation, where the relationship of the price changes to changes in demand and to what extent the impact is measured. The following demand function was obtained:

\section{$\mathrm{D}=1353.99-1.565 \mathrm{P}$}

Where $\mathrm{D}$ is equal to demand, ie, the number of annual passengers in the industry $\mathrm{P}$ and the average market price. It is understood then, that for every unit increase in the price (each dollar) total passengers are reduced in 1565.

Once the demand function is called microeconomics analyzes the price elasticity of demand it is equal to -1.75 and having an absolute value greater than 1 indicates that demand itself is sensitive to a change in prices (Hey, 2004). Microeconomic theory states that have a price-sensitive consumer goods consumers seek substitutes that provide them the same level of utility. So you can say that substitute goods themselves exert force on demand and to the profits of companies in the airline industry.

The airline industry is not exempt and has replacements are those that offer transportation services. Rail services and buses are substitute goods that can be identified without the need for a thorough analysis. Another threatens to industry is that people choose to travel by their own means, as their cars when they need transportation. Microeconomic theory states that two goods are gross substitutes, if an increase in the price increase of one leads to an increase in demand for the other [3]. Then, it is judged whether rail services in these States are substitute goods services offered by airlines. The following data from the Bureau of Transportation Statistics US

It was found that the model has a $\mathrm{R}$ square of 0.420 and 0.372 square $\mathrm{R}$ adjusted, so one can say that the model has a relatively low ratio with the estimated regression equation. Whereas, according to Bureau of Transportation Statistics of the US, the railway is the second most used service by Americans for higher travel 100 miles, only after the airline services, then you can conclude that, at least today, airlines do not have the eminent threat of substitutes.

\section{Bargaining power of buyers}

Contrary to what initially might think, it is important to mention that the service that consumers buy in the industry tends to be standard or undifferentiated, so, as mentioned above, they tend to make purchases in a rational, oriented primarily in the price. This is in accordance with well established structure Porter, where it says that if the industry has low profit, which happens in a competitive market that is studied, then power is given to buyers. Finally, Porter considers information as an important element for the analysis of this force, while buyers have more information, the greater its strength. It is said that currently, by the information technology, buyers enjoy simple information processing. Despite this an advantage of the airline industry in the US it is that buyers have virtually no powernegotiation. According Porter (1982) this because the buyers are not concentrated, ie, many (more than 700 million passengers in 2017 according to the Bureau of 
Transportation Statistics of the US) and not a group of a few. To see if buyers have power overindustry, micro analyzes price elasticity of demand, as stated above, is equal to -1.75 and having an absolute value greater than 1 indicates that the application itself is sensitive to a change in prices [1]. So that consumers do exert force on the demand and to the profits of companies in the airline industry.

\section{Bargaining power of suppliers}

Table 3: Rail service prices (in US dollars based deflation 2017) and passengers on US airlines (in millions).

\begin{tabular}{|c|c|c|}
\hline Year & $\begin{array}{c}\text { Airline Passengers (In mil- } \\
\text { lions) }\end{array}$ & $\begin{array}{c}\text { Rail-Road Service Price } \\
\text { (\$USD) }\end{array}$ \\
\hline 2016 & 720 & 64.5 \\
\hline 2015 & 696 & 66.58 \\
\hline 2014 & 662.8 & 65.93 \\
\hline 2013 & 645.7 & 62.52 \\
\hline 2012 & 642.3 & 60.99 \\
\hline 2011 & 638.2 & 58.99 \\
\hline 2010 & 629.5 & 57.31 \\
\hline 2009 & 618.1 & 58.88 \\
\hline 2008 & 651.7 & 60.28 \\
\hline 2007 & 679.2 & 61.63 \\
\hline 2006 & 658.4 & 57.97 \\
\hline 2005 & 657.3 & 57.69 \\
\hline 2004 & 629.8 & 60.35 \\
\hline 2003 & 583.3 & 55.84 \\
\hline
\end{tabular}

Source: Data from the Bureau of Transportation Statistics US

Table 4: Operating expenses of the consolidate statements of income south-west airlines Co. from 2015 to 2017 (amounts in millions).

\begin{tabular}{|c|c|c|c|}
\hline Operating Expenses & $\mathbf{2 0 1 7}$ & $\mathbf{2 0 1 6}$ & $\mathbf{2 0 1 5}$ \\
\hline Salaries, wages and benefits & 7,319 & 6,798 & 6,383 \\
\hline Fuel and oil & 3,940 & 3,647 & 3,616 \\
\hline Maintenance and repair materials & 1,001 & 1,045 & 1,005 \\
\hline Aircraft rent & 198 & 229 & 238 \\
\hline Landing fees and other income & 1,292 & 1,211 & 1,166 \\
\hline Depreciation and amortization & 1,218 & 1,221 & 1,015 \\
\hline Acquisitions and integrations & - & - & 39 \\
\hline Other operating expenses & 2,688 & 2,514 & 2,242 \\
\hline Total & 17,656 & 16,665 & 15.704 \\
\hline
\end{tabular}

As previously mentioned, based on the competitive market structure, the profits of US airlines are sensitive to the selling price of their service. Understanding that there is a low contribution margin in their operations can conclude that they are also sensitive to the market price of productive factors, especially those that make variable costs. A clear example is the fuel. As shown in Table 3, which represents the expenses, according to these results Southwest Airlines 2015 to 2017, the concept of "fuel oil" is the second largest outflow in operation steadily in years represented the 23.02, 21.88 and 22.31 percent, respectively (Table 4). The dependence of this input for the operation of the airline industry in the United States, and in turn the strong investment buying that represents it, are factors that strengthen industry suppliers. Taking this to the reduction of corporate profits in the industry.

\section{Generic strategies porter}

Once you have identified the five forces that support competition in the industry, Porter suggested three generic strategies that will lead the company to a better position within their industry, ie, increase its benefits (in terms of microeconomic theory). These strategies are cost leadership, product differentiation and focus [4]. Southwest Airlines has positioned itself as a leader in costs as seen in Table 5. It can be estimated that on average in the last 10 years Southwest Airlines holds 32.97 percent price below the market average. This is aligned to its strategy of cost leadership and its outcome has led him to be a market leader.

Table 5: Price comparison Southwest Airlines against market prices for the last 10 years (prices in US dollars with deflation in 2017).

\begin{tabular}{|c|c|c|c|}
\hline Year & Southwest Price & Market Price & Below Market Rate \\
\hline 2017 & 124.4 & 347 & 35.85 \\
\hline 2016 & 127.41 & 354 & 35.99 \\
\hline 2015 & 123.52 & 377 & 32.27 \\
\hline 2014 & 119.73 & 410 & 29.2 \\
\hline 2013 & 153.27 & 401 & 37.93 \\
\hline 2012 & 153.68 & 404 & 38.23 \\
\hline 2011 & 145.5 & 402 & 36.19 \\
\hline 2010 & 121.66 & 377 & 32.22 \\
\hline 2009 & 111.3 & 365 & 30.49 \\
\hline 2008 & 119.94 & 400 & 29.98 \\
\hline 2007 & 109.06 & 388 & 28.11 \\
\hline 2006 & 111.11 & 389 & 28.56 \\
\hline
\end{tabular}

Information calculated the income statements of Southwest Airlines and Information Bureau of Transportation Statistics US

But how microeconomic theory explains the fact Southwest can keep prices below the market and profit in the long term? Well, it is said that a company faces its own demand curve and market demand curve. The difference exists in that the first measures the relationship between the market price and production of the company, while the second measures the relationship between the market price and the total amount sold. Then, by offering lower prices is facing all or at least a part of the market demand [4]. 


\section{Conclusion}

Because of its low barriers to entry, high rivalry among its competitors, its relative elasticity of demand at the price offered opportunity to substitute goods and power of suppliers of productive factors, it might seem that the airline industry in the United States other than one that offers benefits to its participants. But cost leadership strategies have led to Southwest Airlines to be a profitable venture for more than four decades and currently the market leader. This case study contributes to the understanding and usefulness of view based on the industry, showing how to analyze, based on the information obtained to decide what strategies to take.

The binomial here used in industrial organization, where symmetry between the definition of concepts found not only reinforces the fact that they are disciplines that lead hand businesses to better understand their environment and improve their market position [7-9]. As points to deepen future works can be considered based on resources and capabilities vision, which explains what happens strategically within the organization, explaining its concepts from microeconomics theory with the producer. To complete the "rules of the game" and the environment in which the company develops, the study by vision based on institutions hand with economic theory and assumptions of the state as an economic agent and market failures.

\section{References}

1. https://www.bts.gov/

2. Hey J (2004) Microeconomic Intermedia. McGraw-Hill, Mexico.

3. Nicholson W, Snyder C (2015) Microeconomic Theory: Basic Principles and Applications. Cengage Learning, Mexico.

4. Peng M (2012a) Global Strategy. Cengage Learning, Mexico.

5. Peng M (2012b) Global Business. Cengage Learning, Mexico.

6. Porter M (1982) Competitive strategy. Group Editorial Patria, Mexico.

7. Porter M (1987) Competitive advantage. Continental Publishing Company, Mexico.

8. https://www.swamedia.com/

9. https://www.statista.com/statistics/273941/prices-of-boeing aircraftby-type /
Creative Commons Attribution 4.0

International License

For possible submissions Click Here

\section{Submit Article}

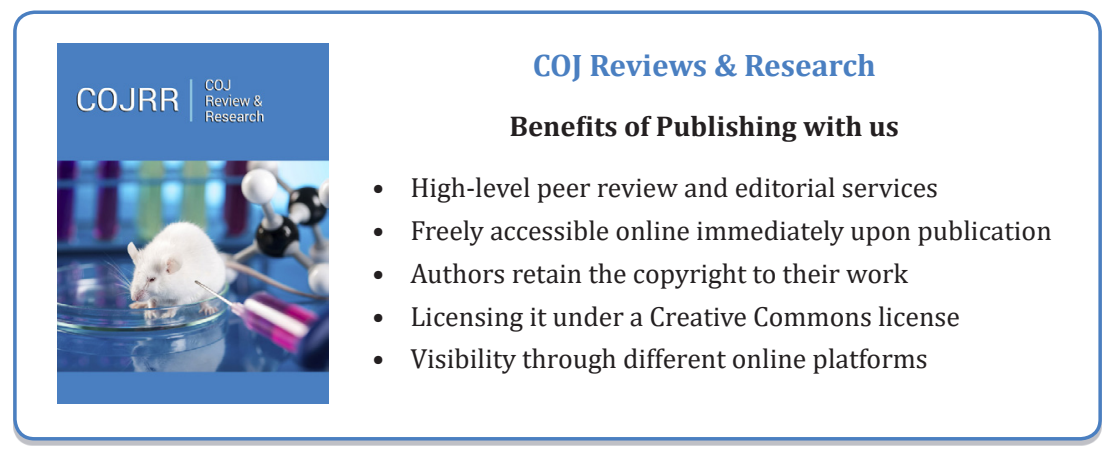

